\title{
Sustainability of Nile tilapia net-cage culture in a reservoir in a semi-arid region
}

\author{
R.S.T. Moura ${ }^{\mathrm{a}, *}$, W.C. Valenti ${ }^{\mathrm{b}}$, G.G. Henry-Silva ${ }^{\mathrm{c}}$ \\ a Rodrigo Sávio Teixeira de Moura, Universidade Federal Rural do Semi-Árido (UFERSA), Animal Sciences Postgraduate Program, \\ Animal Sciences Department, Av. Francisco Mota 572, Costa e Silva, Mossoró, RN 59625-900, Brazil \\ ${ }^{\mathrm{b}}$ Wagner Cotroni Valenti, Universidade Estadual Paulista Júlio de Mesquita Filho, Campus do Litoral Paulista - São Vicente, Infante Dom Henrique Square, \\ Bitaru, São Vicente, SP 11330-900, Brazil

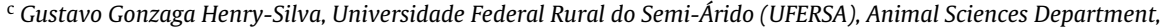 \\ Limnology and Water Quality Laboratory, Av. Francisco Mota 572, Costa e Silva, Mossoró, RN 59625-900, Brazil
}

\section{A R T I C L E I N F O}

\section{Article history:}

Received 28 September 2015

Received in revised form 20 January 2016

Accepted 27 January 2016

Available online 26 February 2016

\section{Keywords:}

Aquaculture modeling

Sustainability indicators

DPSIR

MULINO

\begin{abstract}
A B S T R A C T
Among the tools used to measure sustainability in aquaculture, sets of indicators allow a holistic view of a system in its social, environmental, and economic dimensions. Approaches that align indicators with models such as the Drivers-Pressure-State-Impact-Response (DPSIR) framework can improve understanding of this sustainability. This study evaluated the sustainability of cage production systems for Nile tilapia in the Santa Cruz Reservoir, to determine whether a set of indicators used with the DPSIR conceptual model was effective to study the sustainability of the system. The 49 indicators used were calculated from information obtained from questionnaires and from monitoring the production system. Sustainability was also modeled and compared with hypothetical scenarios, with different fish stocking densities. The results indicated that the production system is economically feasible, generating profit and distributing income. However, the income generated benefits few people and is not fixed in the community. Environmentally speaking, the system is highly dependent on inputs, especially the nutrients nitrogen and phosphorus, and energy, as well as increasing sedimentation of nutrients in the reservoir. In the social dimension, the venture employs few workers. The modeling showed that the system is potentially sustainable, and that changes in stocking density decreased this sustainability. In summary, the system showed many sustainable features, whereas some others need to be modified to improve the general sustainability.
\end{abstract}

@ 2016 Elsevier Ltd. All rights reserved.

\section{Introduction}

Global consumption of aquatic foods has been increasing in recent decades, driven by the expanding human population and the growing preference for healthy sources of animal protein. Production from capture fisheries has not increased to meet the demand, and therefore aquaculture has dramatically expanded. Aquaculture is one of the fastest-growing food-producing sectors worldwide and provides almost half of all fish for human food (FAO, 2014). Tilapia is the second most-often farmed fish worldwide; production reached 4.82 million tons in 2013, with a farm-gate value of US\$ 8.25 billion (FAO, 2015). In Brazil, aquaculture is expanding faster than farming of terrestrial animals (MPA, 2010), and Nile tilapia is

\footnotetext{
* Corresponding author. Tel.: +55 98991146730.

E-mail addresses: savio.ww@gmail.com (R.S.T. Moura),wcvalenti@gmail.com (W.C. Valenti), gustavo@ufersa.edu.br (G.G. Henry-Silva).
}

the species that is most often farmed. The culture of tilapia in netcages in reservoirs emerged early in this century, with a support from Brazilian government programs (Bueno et al., 2015; Garcia et al., 2014). Despite the rapid growth of aquaculture worldwide and in Brazil, sustainability issues may limit further development.

The concept of sustainability involves habitable environments that maintain themselves over time. Sustainable development was originally defined as a process that supplies present needs without compromising the ability of future generations to supply their own needs (WCED, 1987). Subsequently, many other concepts were added, to include economic features and human interactions with the biosphere (Johnston et al., 2007). It is generally accepted that human well-being is dependent on the interaction of natural capital with built, human and social capital (Costanza et al., 2014). The economic, environmental and social dimensions are referred to as the three pillars of sustainability (Frankic and Hershner, 2003), meaning that sustainable production must be economically feasible, environmentally friendly and socially beneficial. Thus, sustainable 
aquaculture may be defined as the cost-effective production of aquatic organisms, which maintains a harmonious and continuous interaction with the local ecosystem and human communities (Valenti, 2011).

Establishing appropriate tools to evaluate sustainability remains a challenge for studies of sustainable development. Measuring the sustainability of aquaculture is essential in order to attain sustainable systems. Such assessments help investors and policymakers to evaluate different projects, and help scientists and farmers to move farming systems toward sustainable production (Valenti, 2011). The methods used to measure sustainability in aquaculture are the analysis of emergy (Odum, 1986), ecological footprint (Rees and Wackernagel, 1994), life cycle analysis (ISO, 2006), resilience analysis (Holling, 1973), and the use of a set of indicators (Boyd et al., 2007; Valenti, 2011). The first four give an integrated overview of the system, which is very useful. However, they require a huge amount of data, which is difficult to obtain, and focus mainly on the environmental dimension. Conversely, sets of indicators measure the individual components of a system, i.e., characteristics that affect its different features (Heink and Kowarik, 2010). Sets of indicators serve as descriptive tools that reflect scenarios through critical points, facilitating the identification of strengths and weaknesses for sustainable development, which are obscured by other methods.

The DPSIR (Drivers-Pressure-State-Impact-Response) theoretical framework and conceptual model has recently allowed the integration of information from several indicators with management actions, such as public policies applied to aquaculture. The DPSIR is a model of systemic evaluation that provides data about economic, social and environmental interactions in a system, highlighting which actions are the most sustainable to manage a resource, and indicating which indicators are more important (Nobre, 2009; Nobre et al., 2010). This approach has been applied to natural resources in Europe by using computational models such as MULINO mDSS (Giupponi, 2007), which permits an interface between researchers and managers to assist in decision-making.

The present study evaluated the sustainability of a tilapia netcage production system in a reservoir in semiarid northeastern Brazil, by applying a set of indicators. In addition, we assessed whether the selected set of indicators and the DPSIR conceptual model are appropriate to evaluate the sustainability of this production system.

\section{Materials and methods}

\subsection{Study area}

The study was conducted at a fish farm founded by 10 aquatic farmers, who work together in the "Associação dos Aquicultores do Apodi" (AQUAPO, The Aquatic Farmers Association of Apodi). The system consists of $\sim 120$ net-cages of $4 \mathrm{~m}^{3}$ each, which in 2012 produced $\sim 33$ tons of Nile tilapia (Oreochromis niloticus). The net-cages are installed in the Santa Cruz Reservoir, city of Apodi, Rio Grande do Norte, Brazil (Fig. 1). This reservoir is located in the watershed of the Apodi/Mossoró River and has an area of $\sim 3413$ ha, with a maximum storage capacity of $\sim 600,000,000 \mathrm{~m}^{3}$ and a maximum depth of $38 \mathrm{~m}$ during the study period. The climate is semiarid and very warm (BSw'h', according to the Köppen climate classification).

\subsection{Sampling design}

The production of a fish batch was followed for 150 days (April through September 2012), through the entire cultivation cycle. Approximately 21,000 Nile tilapia fingerlings weighing approximately $1 \mathrm{~g}$ were obtained from a hatchery in the state of Ceará. The rearing period is divided into two phases. In the initial growth phase, 3 net-cages of $6 \mathrm{~m}^{3}$ are stocked with $\sim 7000$ fingerlings each, resulting in a density of about $1166 \mathrm{ind} . / \mathrm{m}^{3}$; the fry are then selected and stocked in 22 net-cages during the grow-out phase, with a density of 200 ind. $/ \mathrm{m}^{3}$ until harvesting. The fish were measured and weighed weekly for 42 days (initial growth phase) and then biweekly until harvest. The fish are fed daily at frequencies ranging from 8 times daily (initial phase) to 4 times daily (late phase), with four kinds of commercial feed. The first feed used contains $50 \%$ crude protein and is offered to the fish until they reach $4 \mathrm{~g}$; the second feed has $40 \%$ protein and is offered to fish up to $40 \mathrm{~g}$, which concludes the initial phase of cultivation. In the second phase, the fish receive feed with $32 \%$ protein until they reach

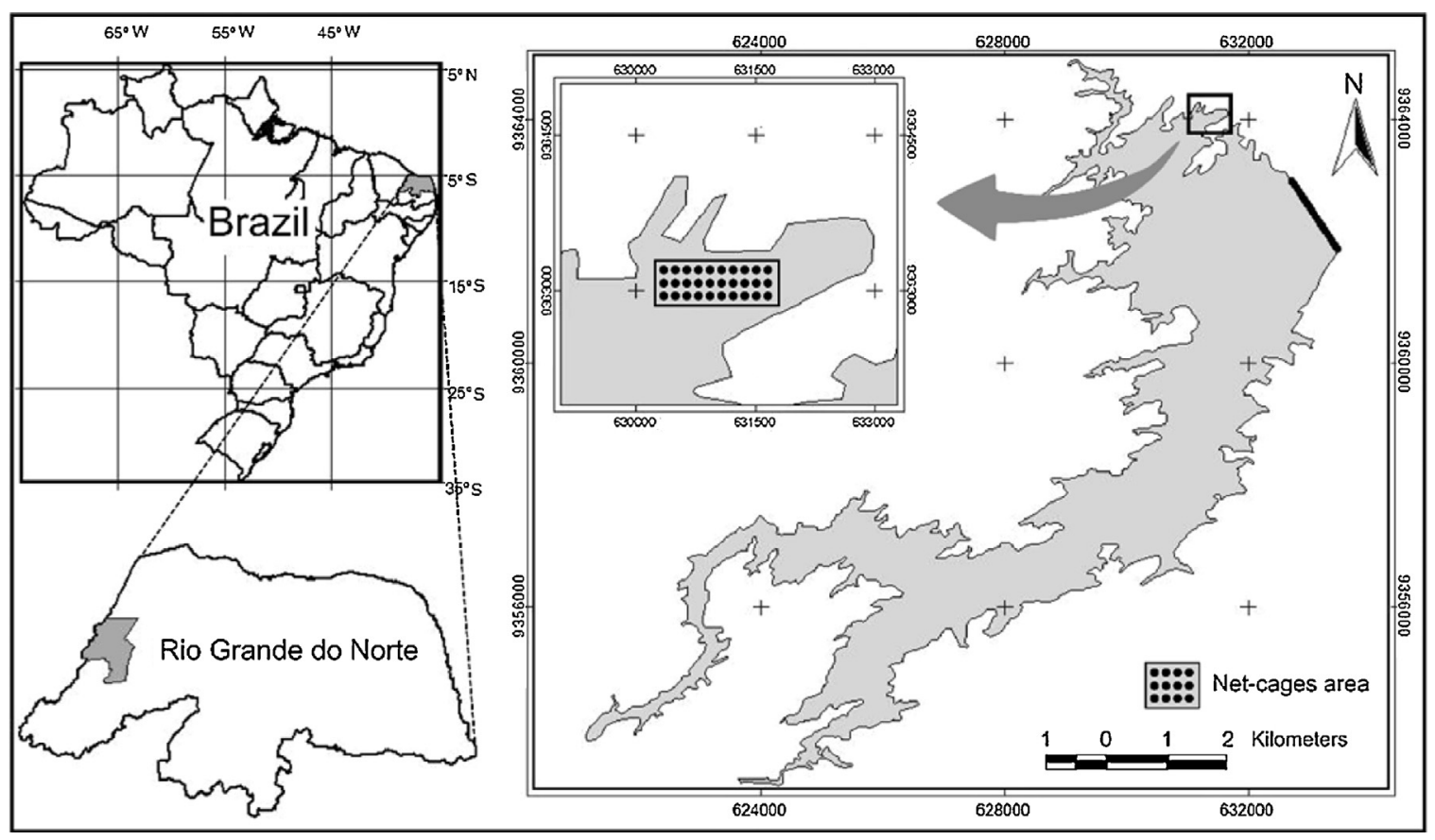

Fig. 1. Location of the Santa Cruz Reservoir, showing the Nile tilapia cage production area. 
Table 1

Technical characteristics of production in the 22 cages monitored.

\begin{tabular}{lc}
\hline Parameter & Value \\
\hline Survival (\%) & 88 \\
Mean initial weight (g) & 1 \\
Mean final weight (g) & 400 \\
Apparent feed conversion & 1.92 \\
Cycles per year & 2.5 \\
Grow-out density (ind./ $\mathrm{m}^{3}$ ) & 200 \\
Production (kg) & 6258.4 \\
\hline
\end{tabular}

$115 \mathrm{~g}$; the last feed, with $28 \%$ crude protein, is supplied until harvest, which starts with fish above $300 \mathrm{~g}$. After the fish reach the appropriate size they are sold locally, whole or fileted. The technical production details are shown in Table 1.

A total of 49 economic, environmental and social indicators were determined (Table 2). They were selected by a panel of actors and stakeholders involved in Brazilian aquaculture, sponsored by the Ministry of Fisheries and Aquaculture of Brazil, using the bottomup method. Some of these indicators were described by Boyd et al. (2007) and Valenti (2011); the others can be found in the complementary material provided here.

\subsection{Economic and social evaluations}

AQUAPO was started with funding from Brazilian government social programs. The amount received by the association was considered as the initial and total investment for calculating the economic indicators. The association kept no records in 2005 and 2006. Therefore, only the six-year period from 2007 through 2012 was used for the economic analyses.

Fixed costs (FC) included employee salaries, permits, and depreciation of assets. Depreciation was calculated by the straight-line method (Shang, 1990). Variable costs (VC) included electric power, fuel, packing, hired labor, feed and fingerlings. We calculated the gross revenue (GR), net revenue (NR) and profit (P) based on the cost and revenue data, as follows:

$\mathrm{GR}=$ Production $\times$ selling price

$\mathrm{NR}=\mathrm{GR}-$ total operating costs

$\mathrm{P}=\mathrm{NR}$ - opportunity costs
All monetary values were converted from Brazilian reals to US dollars, based on the average trading price of the dollar for the period April through September 2012 (US\$ $1.00=\mathrm{R} \$ 1.99$ ).

Interviews were conducted with members of the association, using semi-structured questionnaires to gather the social data. Secondary data including gender, race, ethnicity, and mean income of the local population in the city of Apodi were obtained from websites of institutions such as the "Instituto Brasileiro de Geografia e Estatística” (Brazilian Institute of Geography and Statistics, IBGE).

\subsection{Environmental evaluation}

Samples of the fish stocked and harvested were weighed. The mean initial and final weights, survival, and production of the surviving fish were determined. Inputs and outputs of particulate matter, total nitrogen, total phosphorus, carbon and energy were measured in each compartment of the system, as described below.

\subsubsection{Fish and input compartments}

A sample of the population was weighed to determine the initial biomass at stocking. The total weight of feed provided during the rearing period was calculated, and random samples were collected monthly to determine nitrogen, phosphorus and energy contents. Samples of fish were collected monthly from the start of rearing until harvest. Total nitrogen, total phosphorus, carbon and energy contents were determined for the whole fish in natura, with viscera and scales.

\subsubsection{Water compartment}

Samples of reservoir water were collected monthly to determine particulate matter, total nitrogen, total phosphorus and carbon contents. Sedimentation chambers were installed below three cages at random, in triplicate, once in each month of the rearing period. The chambers remained submerged for $72 \mathrm{~h}$, during which particulate matter released from the cages was collected. Additional chambers were installed, also in triplicate, in an area $400 \mathrm{~m}$ distant from the culture site, to serve as a control for natural sedimentation in the reservoir. The water samples obtained from the sedimentation chambers were taken to the laboratory for analysis.

Table 2

List of indicators of economic, environmental and social sustainability.

\begin{tabular}{|c|c|c|c|}
\hline \multicolumn{4}{|c|}{ Sustainability indicators } \\
\hline & Economic dimension & Environmental dimension & Social dimension \\
\hline 1. & Revenue-investment ratio & Use of space & Salary equity \\
\hline 2. & Internal rate of return & Dependence on water & Labor proportional cost \\
\hline 3. & Payback period & Energy use & Revenue distribution \\
\hline 4. & Benefit-cost ratio & Proportion of renewable energy & Remuneration by production \\
\hline 5. & Net present value & Nitrogen use & Race inclusion \\
\hline 6. & Profit & Phosphorus use & Gender inclusion \\
\hline 7. & Revenue & Efficiency in energy use & Age inclusion \\
\hline 8. & Risk rate & Efficiency in nitrogen use & Work/area \\
\hline 9. & Product diversity & Efficiency in phosphorus use & Work/production \\
\hline 10. & Market diversity & Effectively used production & Generation of direct employment \\
\hline 11. & Invested capital generated in the activity & Eutrophication potential & Generation of labor posts \\
\hline 12. & & Overall pollution & Self employment proportion \\
\hline 13. & & Pollution from hormones & Use of local labor \\
\hline 14. & & Acidification potential & Revenue fixation \\
\hline 15. & & Accumulation of phosphorus & Local consumption \\
\hline 16. & & Accumulation of OM & Health programs \\
\hline 17. & & Accumulation of PM & Education \\
\hline 18. & & Produced species risk & Permanence in the activity \\
\hline 19. & & & Participation of the community \\
\hline 20. & & & Job security \\
\hline
\end{tabular}

OM, organic matter; PM, particulate matter. 


\subsubsection{Sediment compartment}

The sediment generated under each cage was quantified monthly using sedimentation chambers, as explained in the previous section. Each sediment sample was weighed, and the concentrations of total particulate matter and organic fraction were determined according to Bufon et al. (2009). The sedimentation rate in the reservoir caused by factors other than aquaculture was determined using the three sets of sedimentation chambers $400 \mathrm{~m}$ from the culture site in the reservoir.

\subsubsection{Nutrient analyses}

Total nitrogen and total phosphorus in the diet and in the fish were analyzed according to Eaton et al. (2005), methods 4500 NC and 4500 P-B3, respectively. Carbon and energy contents were analyzed using a VARIO-TOC carbon analyzer and an IKA 2000 isoperibol calorimeter, respectively. Concentrations of total nitrogen (Koroleff, 1976), total phosphorus (Golterman et al., 1978) and carbon (VARIO-TOC carbon analyzer) were determined for the water in the sedimentation chambers.

The release of particulate inorganic and organic matter, total nitrogen, total phosphorus, and carbon into the environment was calculated by subtracting the values obtained for the water, the sediment in the water, and the sediment collected in the control region from the same parameters measured under the production cages.

\subsection{DPSIR modeling}

The model was implemented with the software Multisectorial, Integrated and Operational Decision Support System for Sustainable Use of Water Resources at the Catchment Scale (MULINO mDSS) v5.12 (Giupponi, 2007). Similarly to the input data in this model, a subset of the initial set of indicators was used, totaling 20 indicators distributed among the three dimensions of sustainability and the five DPSIR criteria (Table 3). Indicators that specifically reflect changes related to different stocking densities were selected to compose this subset. The selected indicators were entered into

Table 3

Indicators used as input in MULINO for the DPSIR modeling.

\begin{tabular}{|c|c|c|c|}
\hline Indicator & Weigth & Criteria & Primary dimension \\
\hline Dependence on water & 0.038 & Driving force & Environmental \\
\hline Profit & 0.038 & Driving force & Economic \\
\hline Production & 0.038 & Driving force & All \\
\hline $\begin{array}{l}\text { Revenue-investment } \\
\text { ratio }\end{array}$ & 0.038 & Driving force & Economic \\
\hline Revenue & 0.077 & Driving force & Economic \\
\hline Work/production & 0.038 & Driving force & Social \\
\hline Use of space & 0.038 & Driving force & Environmental \\
\hline Accumulation of MO & 0.077 & Pressure & Environmental \\
\hline Accumulation of PM & 0.038 & Pressure & Environmental \\
\hline Energy use & 0.038 & Pressure & Environmental \\
\hline Nitrogen use & 0.038 & Pressure & Environmental \\
\hline Phosphorus use & 0.038 & Pressure & Environmental \\
\hline Labor proportional cost & 0.077 & State & Social \\
\hline Efficiency in energy use & 0.038 & State & Environmental \\
\hline $\begin{array}{l}\text { Efficiency in nitrogen } \\
\text { use }\end{array}$ & 0.038 & State & Environmental \\
\hline $\begin{array}{l}\text { Efficiency in } \\
\text { phosphorus use }\end{array}$ & 0.038 & State & Environmental \\
\hline Benefit-cost ratio & 0.077 & State & Economic \\
\hline $\begin{array}{l}\text { Remuneration per } \\
\text { production }\end{array}$ & 0.077 & State & Social \\
\hline Acidification potential & 0.038 & Impacts & Environmental \\
\hline $\begin{array}{l}\text { Eutrophication } \\
\text { potential }\end{array}$ & 0.077 & Impacts & Environmental \\
\hline $\begin{array}{l}\text { Changes in the } \\
\text { indicators }\end{array}$ & & Response & All \\
\hline
\end{tabular}

OM, organic matter; PM, particulate matter.
Table 4

Performance scale used in the classification of sustainability for the modeled scenarios (Valenti, 2008)

\begin{tabular}{cl}
\hline Range & Classification \\
\hline $0-20$ & Not sustainable \\
$20-40$ & Low sustainability \\
$40-60$ & Medium sustainability \\
$60-80$ & Potentially sustainable \\
$80-100$ & Sustainable \\
\hline
\end{tabular}

the program and then were grouped according to the DPSIR criteria, which considers: (i) indicators of driving forces, which is the activity of cage aquaculture; (ii) indicators of pressure on the ecosystem; (iii) status indicators of current conditions in the system; (iv) indicators of the impacts caused by the activity; and (v) possible responses in terms of management to mitigate impacts. A sensitivity analysis was performed with a software subroutine. This analysis evaluates the behavior of the modeled scenarios in response to changes in each indicator individually, and indicates which are the most important to the system. Indicators in which minor changes strongly influence the sustainability are considered to be the most important to the system. These indicators received twice the weight of the others in the modeling process.

The current (actual) sustainability of the cultivation system was evaluated under this framework, and was compared with four other alternative (hypothetical) scenarios. The five scenarios considered were for different stocking densities: (a) DENS 225, hypothetical scenario where the system operates with a stocking density of 225 ind. $/ \mathrm{m}^{3}$; (b) DENS 200 , as currently practiced, where the system operates with a stocking density of 200 ind./ $\mathrm{m}^{3}$; (c) DENS 175 , hypothetical stocking density of 175 ind./ $\mathrm{m}^{3}$; (d) DENS 150, hypothetical stocking density of 150 ind./ $\mathrm{m}^{3}$; (e) DENS 125 , hypothetical stocking density of $125 \mathrm{ind} . / \mathrm{m}^{3}$. The indicators were selected to allow simulation of their behavior and values for the four alternative scenarios considered. The decision algorithm used was SAW (Simple Additive Weighting).

The MULINO software performs a comparative analysis, which calculates the performance of the indicators in each scenario. Each indicator is assigned a value from 0 to 100 , with 0 being the least sustainable and 100 being the most sustainable. The four hypothetical alternative scenarios and the actual current one were classified at the end of the modeling by their sustainability in the three dimensions as well as their overall sustainability, with a subindex being assigned to each scenario per dimension evaluated, and indices of overall sustainability. The alternative and actual scenarios were then framed according to a performance scale (Table 4).

The scale used considered the sustainability range calculated by MULINO software (0-100), divided into five classes with equal intervals. Thus, the class "not sustainable" indicates a scenario without sustainable features and that is far from a state of sustainability. Classes "low" and "medium sustainability" suggest scenarios that are also not sustainable, despite having some more sustainable characteristics than the previous class. The class "potentially sustainable" represents a transitional scenario to sustainability, i.e., the system may become sustainable with some minor modifications. The last class, "sustainable", is a scenario in which the system was considered sustainable for most of the indicators calculated.

\section{Results}

\subsection{Indicators of economic sustainability}

The establishment of the AQUAPO farm was funded by Brazilian government social programs in 2005. The initial funds paid for net cages, the first fingerlings, feed and fuel, and for technical training 
Table 5

Production, revenues and expenditures of AQUAPO. Cost = total operating cost + total fixed cost (US\$ $1.00=\mathrm{R} \$ 1.99$ ).

\begin{tabular}{lllrl}
\hline Year & Production $(\mathrm{t})$ & $\begin{array}{l}\text { Selling } \\
\text { price }(\$)^{\mathrm{a}}\end{array}$ & Revenue $(\$)$ & Costs $(\$)$ \\
\hline 2007 & 12.4 & 2.51 & 27368.42 & 18646.62 \\
2008 & 22.4 & 2.76 & 50526.32 & 35368.42 \\
2009 & 18.7 & 3.01 & 49724.31 & 29994.99 \\
2010 & 22.4 & 3.01 & 59498.75 & 36491.23 \\
2011 & 31.3 & 3.26 & 110877.19 & 50989.97 \\
2012 & 33 & 3.51 & 88571.43 & 57894.74 \\
\hline
\end{tabular}

a Maximum price per kilogram in the period.

Table 6

Cash flow for the years 2007-2012 (US\$1.00=R\$1.99).

\begin{tabular}{lccrr}
\hline Year & Cash inflows & \multicolumn{2}{l}{ Cash outflows } & \multirow{2}{*}{$\begin{array}{l}\text { Net cash } \\
\text { flow }(\$)\end{array}$} \\
\cline { 3 - 4 } & Revenue $(\$)$ & Investment $(\$)$ & Costs $(\$)$ & \\
\hline 0 & - & 9723.35 & - & -9723.35 \\
1 & 27368.42 & 0.00 & 18646.62 & 8721.80 \\
2 & 50526.32 & 0.00 & 35368.42 & 15157.89 \\
3 & 49724.31 & 0.00 & 29994.99 & 19729.32 \\
4 & 59498.75 & 0.00 & 36491.23 & 23007.52 \\
5 & 110877.19 & 0.00 & 52558.90 & 58318.30 \\
6 & 88571.43 & 0.00 & 57894.74 & 30676.69 \\
\hline
\end{tabular}

for the associates. Currently, the venture functions with its own resources.

AQUAPO did not invest capital because the initial investment to start the activities and the subsequent annual investments were received from funding organizations to maintain and promote fish culture in the region. Therefore, the capital from government programs was considered as investment for the purpose of calculating the costs of the venture. This included the initial investment of US\$ 9718.84 in 2005; US\$ 33583.96 during 2006-2008; and US\$ 40100.25 during 2009-2012. The grand total was US\$ 83407.56 from the start of the activities until the time of the study. The components of the capital included feed, fingerlings, cages, and other, minor expenses, which were calculated and separated into fixed and variable costs.

Production, selling price, gross revenues, and total expenses during the years are summarized in Table 5. The net cash flow was positive in all years (Table 6). This demonstrates the liquidity of the project over time and confirms its economic feasibility.

The indicators of economic sustainability showed that the system is economically feasible, since it demonstrates an internal rate of return greater than the attractive rate of return (considered equal to $8 \%$ ) (Table 7). The positive net present value reinforces the position of the venture as economically valid, whereas the benefit-cost ratio indicates that each US\$ 1.00 invested yielded US\$ 1.34 in benefits for those involved. Nevertheless, the ratio of mean annual income to investment was relatively high. Profit and income were considered economically satisfactory.

Table 7

Indicators of economic sustainability.

\begin{tabular}{ll}
\hline Indicator & Result \\
\hline 1. Revenue-investment ratio & $\$ 2.67$ \\
2. Internal rate of return & $52 \%$ \\
3. Payback period & 3.22 years \\
4. Benefit-cost ratio & $\$ 1.35$ \\
5. Net present value & $\$ 47773.09$ \\
6. Profit & $\$ 10361.65$ \\
7. Revenue & $\$ 12360.42$ \\
8. Risk rate & $75 \%$ \\
9. Product diversity & 5 \\
10. Market diversity & 5 \\
11. Invested capital generated in the activity & $\$-$ \\
\hline
\end{tabular}

Table 8

Indicators of environmental sustainability.

\begin{tabular}{ll}
\hline Indicator & Result \\
\hline 1. Use of space & $0.01 \mathrm{~m}^{2} / \mathrm{kg}$ \\
2. Dependence on water & $4.69 \mathrm{~m}^{3} / \mathrm{t}$ \\
3. Energy use & $98.02 \mathrm{MJ} / \mathrm{kg}$ \\
4. Proportion of renewable energy & $0 \%$ \\
5. Nitrogen use & $82.49 \mathrm{~kg} \mathrm{~N} / \mathrm{t}$ \\
6. Phosphorus use & $10.39 \mathrm{~kg} \mathrm{P} / \mathrm{t}$ \\
7. Efficiency in energy use & $5 \%$ \\
8. Efficiency in nitrogen use & $21 \%$ \\
9. Efficiency in phosphorus use & $17 \%$ \\
10. Effectively used production & $89 \%$ \\
11. Eutrophication potential & $56.95 \mathrm{~kg} \mathrm{P} / \mathrm{t}$ \\
12. Overall pollution & $0.00 \mathrm{~kg} / \mathrm{kg}$ \\
13. Pollution from hormones & $0.00 \mathrm{~kg} / \mathrm{kg}$ \\
14. Acidification potential & $7.68 \mathrm{~kg} \mathrm{~S} / \mathrm{t}$ \\
15. Accumulation of phosphorus & $0.88 \mathrm{~kg} \mathrm{P} / \mathrm{t}$ \\
16. Accumulation of OM & $67.20 \mathrm{~kg} \mathrm{MO} / \mathrm{t}$ \\
17. Accumulation of PM & $78.90 \mathrm{~kg} \mathrm{MP} / \mathrm{t}$ \\
18. Produced species risk & 5.00 \\
\hline
\end{tabular}

\subsection{Indicators of environmental sustainability}

The indicators of environmental sustainability showed low dependence on water (less use) in comparison with other production systems like raceways and ponds (Boyd et al., 2007). The system in this study utilized an area of $0.01 \mathrm{~m}^{2} / \mathrm{kg}$ of fish produced and a volume of $4.7 \mathrm{~m}^{3} /$ ton (Table 8 ). The system, however, showed inefficiencies in the use of nutrients and energy, as only $21 \%$ of nitrogen, $17 \%$ of phosphorus and $5 \%$ of the energy used for production was recovered in animal biomass. The system also released particulate matter at $0.08 \mathrm{~kg} / \mathrm{kg}$ of fish produced. Approximately $90 \%$ of this was organic matter, generating $0.07 \mathrm{~kg}$ of organic matter per kilogram of fish. The eutrophication potential was estimated at $56.95 \mathrm{~kg}$ of phosphorus released per ton of fish produced. The potential for acidification of the environment was estimated at $7.68 \mathrm{~kg}$ of sulfur released per ton of fish produced. Pollution from herbicides, pesticides and hormones was zero, since none of these products were used.

\subsection{Indicators of social sustainability}

The indicators of social sustainability showed that the work required is 29 man-hours-year per square meter $\left(\mathrm{MHY} / \mathrm{m}^{2}\right)$, or 0.4 man-hours per kilogram of fish produced $(\mathrm{MH} / \mathrm{kg})$. The system still produces an income distribution of $\sim$ US $\$ 2.00$ and remuneration of relevant labor at $\sim$ US\$ 1.30 per kilogram of fish produced. By treating it as an association, the members receive equal pay, i.e., the salary equity of the system is $100 \%$. The inclusion of race (55\%) and age (66\%) is reasonable, while the inclusion of gender $(48 \%)$ is not satisfactory because the association is comprised of men only. A drawback of the system is the generation of only a small number of jobs and direct employment, considering the amount invested in the venture. Only $2 \%$ of the total cost (fixed and variable costs over time) is spent locally, but taking into account that the associates spend their salaries in the city, the income fixation was estimated at $44 \%$ (Table 9 ).

\subsection{Modeling of sustainability}

The modeling revealed that the scenarios evaluated are similar to each other with respect to the sustainability pillars (Fig. 2), except the 125 ind. $/ \mathrm{m}^{3}$ scenario. This scenario showed that the sustainability is skewed toward the environmental dimension. The sub-indices of sustainability showed that the scenario with the highest density (DENS 225) was the most economically sustainable, the scenario with the intermediate density (DENS 175) was the 
Table 9

Indicators of social sustainability.

\begin{tabular}{ll}
\hline Indicator & Result \\
\hline 1. Salary equity & $100 \%$ \\
2. Labor proportional cost & $42 \%$ \\
3. Revenue distribution & $\$ 2.06$ \\
4. Remuneration by production & $\$ 1.29 / \mathrm{kg}$ \\
5. Race inclusion & $55 \%$ \\
6. Gender inclusion & $48 \%$ \\
7. Age inclusion & $66 \%$ \\
8. Work/area & $29.75 \mathrm{MHY} / \mathrm{m}^{2}$ \\
9. Work/production & $0.44 \mathrm{MH} / \mathrm{kg}$ \\
10. Generation of direct employment & $\ll 0 \mathrm{jobs} / \$$ \\
11. Generation of labor posts & $\ll 0 \mathrm{jobs} / \$$ \\
12. Self employment proportion & $100 \%$ \\
13. Use of local labor & $100 \%$ \\
14. Revenue fixation & $44 \%$ \\
15. Local consumption & $100 \%$ \\
16. Health programs & $0 \%$ \\
17. Education & $10 \%$ \\
18. Permanence in the activity & $3.25 \mathrm{years}$ \\
19. Participation of the community & $100 \%$ \\
20. Job security & $91 \%$ \\
\hline
\end{tabular}

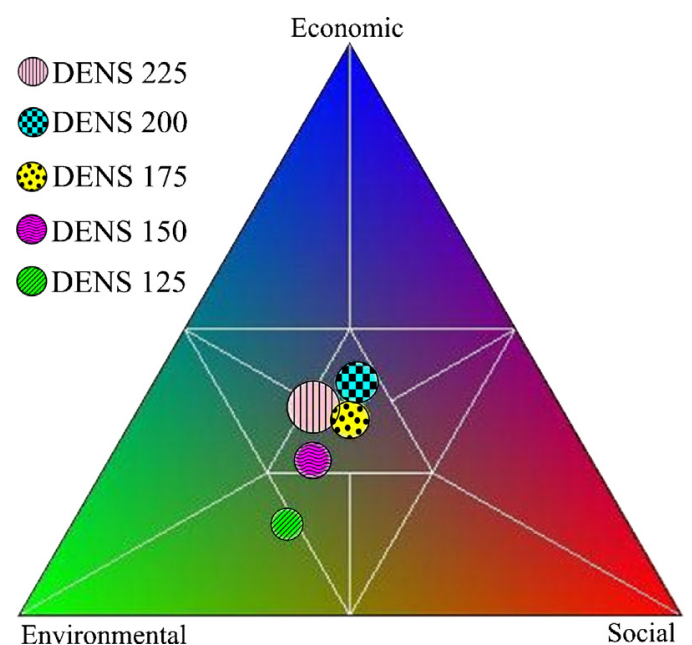

Fig. 2. Triangle of sustainability for the current scenario (DENS 200) and the four hypothetical scenarios. DENS $125-225$, stocking densities of $125-225$ ind./ $\mathrm{m}^{3}$.

most socially sustainable, and the scenario with the lowest density (DENS 125) was the most environmentally sustainable (Table 10).

The skewing of sustainability toward one of the pillars works to the detriment of the other two pillars, and therefore the general index of sustainability indicated that the current system (DENS 200) is the most sustainable, being classified as "potentially sustainable". The DENS 125 scenario was classified as "low sustainability", while the other scenarios (DENS 225, DENS 175, and DENS 150) were classified as "average sustainability", according to the classification scale used for this study (see Table 4).

Table 10

Sustainability scores for each dimension considered in each hypothetical scenario plus the current one, and the general index of sustainability. Scores in bold indicate the most sustainable scenario for each dimension and for the general index.

\begin{tabular}{lllll}
\hline \multirow{2}{*}{ Cenario } & \multicolumn{2}{l}{ Score } & Index \\
\cline { 2 - 3 } & Env & Soc & Eco & \\
\hline DENS 225 & 29 & 31 & $\mathbf{4 0}$ & 51 \\
DENS 200 & 37 & 26 & 37 & $\mathbf{6 5}$ \\
DENS 175 & 33 & $\mathbf{3 3}$ & 34 & 46 \\
DENS 150 & 42 & 31 & 27 & 42 \\
DENS 125 & $\mathbf{5 1}$ & 32 & 17 & 38 \\
\hline
\end{tabular}

\section{Discussion}

\subsection{Economic dimension}

The AQUAPO system showed potential economic sustainability, and is financially feasible based on the indicators used. The classic economic indicators of internal rate of return (IRR) and net present value (NPV) showed overall satisfactory and attractive values, demonstrating that the system generates financial benefits and produces a monetary return. The financial benefits and monetary return enabled profitability and sufficient annual income to keep the system functioning and generating more income over time. Campos et al. (2007) calculated an IRR of $57 \%$ and a positive NPV for a private fish farm system, showing that it is highly economically viable. The AQUAPO system showed an IRR of $52 \%$, a positive NPV, and a payback period of more than three years. These indicators reflect the ability of the system to convert the cost of the venture, indicating that the community-association structure can generate attractive financial returns.

The AQUAPO cultivation system was considered sufficiently profitable, with a 23\%/year profit. Sabbag et al. (2007) found a profitability of $22.6 \%$ in Nile tilapia cage production as managed by an association, similar to the present study. The high profitability of association ventures is due to tax exemptions and economic subsidies offered for sustainable development, which lower costs and consequently generate greater profitability. The AQUAPO system showed a short payback period. This contrast is probably more related to the difficulties with management and resource administration that are inherent to associations. Thus, the AQUAPO system showed an internal rate of return and profitability that make it quite feasible.

The risk rate of $25 \%$ indicates high sustainability and the existence of few economic risk factors for the venture. The relationship between the average annual income and the initial investment was satisfactory (US\$2.67), demonstrating that the amount invested was transformed efficiently into income. However, the capital reinvested in the venture was considered equal to zero, since the government invested throughout the life of the project, as expressed by the invested capital generated in the activity. The amount of products offered and the number of markets reached were suitable for the enterprise, which did not decrease the sustainability since the entire production can be used and can meet local demand.

\subsection{Environmental dimension}

The AQUAPO production system showed moderate environmental sustainability. Cage production of tilapia requires relatively little space and water (Boyd, 2005). This increases the overall sustainability of the system, since it allows high productivity in a small volume of water, i.e., only the water used during the rearing process. Thus, environmental sustainability problems related to water use are less influenced by water use per se, and are associated more with the generation of waste, organic pollution, and introduction of exotic species. Verdegem and Bosma (2009) suggested that global aquaculture production can be tripled without increasing water use. More-efficient techniques would increase production while generating less waste, fewer escapes of exotic species, and higher rates of conversion of nutrients to biomass without expanding the activity in terms of the space used.

Intensive culture systems depend highly on feed with high protein levels, leading to a high nutrient use for production. The amounts of nitrogen and phosphorus used in this study were $\sim 80 \mathrm{~kg}$ and $10 \mathrm{~kg} /$ ton of fish produced, respectively. These levels are higher than those found by Almeida (2013), who estimated that $2 \mathrm{~kg}$ of phosphorus and $7 \mathrm{~kg}$ of nitrogen were used for each ton of tilapia 
produced in a cage system. Thus, the amount of nutrients used in the AQUAPO system is comparatively high; however, the use efficiency should be considered. The evaluation revealed that most of the nutrients and energy added to the system are lost to the environment and not transformed into animal biomass. Inefficient use of nutrients threatens the sustainability of aquaculture, as demonstrated for various culture systems by Boyd (2006) and Boyd and Tucker (1998).

The percentage of each nutrient recovered in the biomass harvested was $21 \%$ of the nitrogen and $17 \%$ of the phosphorus applied; only $5 \%$ of the energy used in feed, work, labor and fossil fuels was recovered in the form of animal biomass. Boyd et al. (2007) calculated that the biomass harvested recovers up to $40 \%$ of the phosphorus and $22.5 \%$ of the nitrogen applied from feed to cage production of Nile tilapias. Some $11 \%$ of the recovery is also lost in the form of unconsumed animal biomass, which then becomes waste. The results from Boyd et al. (2007) are higher than the levels observed here, indicating that the AQUAPO system is less efficient for the conversion of nutrients, especially phosphorus, into animal biomass. This discrepancy relates to the quality of feed used; lower structural and nutritional quality leads to greater loss of nutrients to the environment and simultaneously lower retention of these nutrients in animal biomass. The results obtained from this study also concord with observations by Almeida (2013), who estimated a recovery of $24 \%$ of nitrogen and phosphorus applied and of $6 \%$ of the energy applied to the tilapia biomass in cage production. It is evident that this type of system uses only part of the resources offered, consequently generating a larger amount of waste exported to the environment.

The quantity and quality of protein in commercial feeds present a challenge for the sustainability of production systems, since the use of high-protein diets with low protein quality (low digestibility and assimilation efficiency) leads to unsustainable use of this nutrient. The apparent feed-conversion rate is a significant focus of fish production because it reflects the percentage of the feed applied to the system that is transformed into fish biomass. Almeida (2013), using a conversion rate of 1.63 , found better results for nutrient efficiency than in the AQUAPO system, which showed lower nutrient efficiency and a conversion rate of 1.95 . Although the apparent feed conversion rate is not the best alternative to estimate feed consumption because it disregards the feed that is not consumed Valenti (2012), this indicator is a useful representative of the amount of waste that the system might produce.

The potential for overall pollution from the system, considered as the total emissions from phosphorus, sulfur, hormones, herbicides and other pesticides, is relatively low. Specifically, the system released $\sim 56.95 \mathrm{~kg}$ of phosphorus and $\sim 7.68 \mathrm{~kg}$ of sulfur per ton of fish produced, and did not release pesticides, herbicides, or hormones since none were used. A low accumulation of phosphorus $(0.9 \mathrm{~kg} /$ ton of fish $)$ in the sediment, combined with a reduced potential for pollution, suggests that the AQUAPO production system is relatively environmentally sustainable. Studies such as that of Almeida (2013) show that cage systems release more than $150 \mathrm{~kg}$ of phosphorus per ton of fish produced per year, as sediment into the aquatic environment. The present results showed that $\sim 30 \mathrm{~kg}$ of phosphorus was released into the reservoir for 233 tons of fish produced in the year 2012. The average annual amount of phosphorus released into the sediment since the start of the venture (including 2012) was $\sim 20.6 \mathrm{~kg}$.

Solid wastes generated by the system totaled $\sim 80 \mathrm{~kg} /$ ton of fish produced. This implies that the system generated $\sim 2640 \mathrm{~kg}$ of solid waste from 33 tons of tilapia produced in 2012. Similarly, Almeida (2013) considered that the release of sediments was the main environmental impact from intensive cage production in open water. This level of waste, however, is lower than in other cage systems. Azevedo et al. (2011) calculated the amount of solid waste as $\sim 200 \mathrm{~kg} /$ ton of trout produced in cages, which is more than twice the amount found in this study. These results show that although waste generation is significant, the AQUAPO system can still be considered sustainable compared to other rearing systems.

The continuous input of solid waste to the environment from cage production increases the concentrations of total nitrogen and phosphorus in the sediment, as observed below the cages and in adjacent areas. The increase in nutrients in the sediment is significant over time, considering that $\sim 90 \%$ of the waste generated is organic material. The accumulation of suspended solids over time in reservoirs alters the conditions in the sediment, which is evident in the rearing area and in nearby areas, as observed by Huang et al. (2012) and Guo and Li (2003) for cage production of various species in China. The results of the present study concord with observations elsewhere that environmental sustainability was strongly influenced by the generation of solid waste, a major impediment for sustainable production.

\subsection{Social dimension}

The AQUAPO venture demonstrated moderate sustainability in its social dimension. The association model somewhat affects the sustainability, since the venture employs only local residents. All of the associates participate in community activities, they own the enterprise, and the profits are divided equally among all members, giving a salary equity of $100 \%$. On the other hand, this decreased sustainability because fewer direct-employment and laboring jobs were created, for relatively few beneficiaries.

The use of local labor emphasizes and elevates the social value of the activity. This idea contrasts, however, with the small number of associates needed for the little work required per area for this type of production system. Consequently, the number of people benefiting from the activity is still small. If each associate is considered to represent a family, the generation and distribution of income from the venture becomes more socially important. The project is also socially important because it includes people with a low education level (only one of the associates studied) and of different ages and races, and is limited only to the employment of men in the activities. Even though the venture is socially important, the associates remained active in the association for only 3.25 years on average, i.e., less than half of the 7-year period that the association existed.

All of the production is consumed by the local community, which indicates that the rearing project increases the supply and quality of animal protein available. The fish are sold to members of social classes with both higher and lower purchasing power, and to municipal school lunch programs through government subsidies. This indicator of consumption reflects the improvements in the quality of life in the local community provided by the activity.

The generation of direct income and jobs related to the capital invested in the venture was low, since few associates continued to participate in the project. This indicator suggests that cage-production systems require little physical labor to maintain operations, despite the indication of low social sustainability. The pay is relatively low (less than US\$ 1.50 per associate per kilogram produced), which influences other indicators such as access to health-care programs. None of the AQUAPO associates possessed health insurance. The venture showed an income distribution at US\$ 2.00; in other words, US\$ 2.00 is spent on labor for each US\$ 1.00 of profit that the system generates. This compensation represents $42 \%$ of the production costs. The venture pays the labor a value that is double the profit from the activity, and a portion of the production costs is also paid to the associates. This indicates that the project generates social benefits and improves the quality of life for those involved.

The indicator of income fixation showed that $44 \%$ of the income generated by the venture remains in the local community, including 
the wages paid to labor and the costs of the venture in the local market. More than half of the revenue generated by the activity does not remain in the community where it takes place, however, which diminishes the power of the venture to provide social and local economic development. If the income fixation is scaled up to the state level, the income fixation is reversed and shows that more than $90 \%$ is fixed within the state, i.e., a relatively small proportion of the financial resources is exported to other states.

\subsection{Modeling of sustainability}

The production system was shown to be potentially sustainable, as modeled using the indicators. Comparing the current system with the four hypothetical scenarios showed that the real scenario was the most sustainable and balanced among those considered, where the economic, environmental, and social dimensions received similar scores. Even though it is the most sustainable in absolute terms, the current system still did not perform best for sustainability when the dimensions were analyzed individually. This makes it clear that sustainability should neither be assessed from a unilateral point of view, nor evaluated through only one aspect of its multidimensional space. Furthermore, sustainability depends on balancing the production system according to all of the dimensions, rather than attaining a high sustainability in a single dimension at the expense of the other dimensions considered.

It became evident that increasing the stocking density in this system was not sustainable, even though this density would benefit the system economically, generating more income and profitability and producing a better benefit-cost ratio. From the social point of view, the additional benefits would consist of slightly improving working conditions and the quality of life for members of the association, minutely improving only the remuneration of labor. Using a higher density would increase waste releases to the environment from an increased use of feed, with no improvement in use efficiency.

The least-sustainable scenario (DENS 125) was quite environmentally friendly and showed high environmental sustainability, but was barely feasible from the other dimensions analyzed. Environmental sustainability is favored since lower production uses less environmental resources and generates less waste. The venture becomes economically unsustainable since a low stocking density decreases gross production, which ultimately decreases the return and the profitability. Social sustainability is reduced when the associates perform the same work required for less production, thus lowering the income distributed to the beneficiaries.

\section{Conclusion}

The cage-production system of Nile tilapia in the Santa Cruz Reservoir was found to be potentially sustainable overall. The system was considered economically sustainable while being less sustainable with respect to the environmental and social dimensions. Even though the system was not considered sustainable, we can infer that it is in a state close to sustainability, or yet, in a development state toward sustainability. The main factors that reduced the sustainability of the project were the generation of solid wastes, the relative inefficiency in the use of nutrients, low generation of direct employment, and small amount of income fixation in the local community. Modifications in these factors are essential to improve the sustainability of the system.

We also concluded that the set of indicators adequately evaluates sustainability in aquaculture, and was able to reflect the main strengths and weaknesses of this system. The importance of the DPSIR model for evaluating sustainability was evident in its performance in highlighting the most important indicators for the system, and in providing a holistic view of sustainability with respect to the three dimensions analyzed.

\section{Acknowledgments}

The authors acknowledge Janet $\mathrm{W}$. Reid for correcting the English text; the Fundação de Amparo a Pesquisa do Estado do Rio Grande do Norte (FAPERN), Conselho Nacional de Desenvolvimento Científico e Tecnológico (CNPq) Coordenação de Aperfeiçoamento de Pessoal de Nível Superior (CAPES) and Fundação de Amparo a Pesquisa do Estado de São Paulo (FAPESP) for the financial support and the scholarships.

\section{Appendix A. Supplementary data}

Supplementary data associated with this article can be found, in the online version, at http://dx.doi.org/10.1016/j.ecolind.2016. 01.052.

\section{References}

Almeida, R., (thesis) 2013. Indicadores de sustentabilidade do cultivo de Tilápiado-nilo (Oreochromis niloticus) em tanques-rede em um reservatório tropical. Universidade Estadual Paulista, Jaboticabal.

Azevedo, P.A., Podemski, C.L., Hesslein, R.H., Kasian, S.E.M., Findlay, D.L., Bureau, D.P., 2011. Estimation of waste outputs by a rainbow trout cage farm using a nutritional approach and monitoring of lake water quality. Aquaculture 311, 175-186, http://dx.doi.org/10.1016/j.aquaculture.2010.12.001.

Boyd, C.E., 2006. Effluent effects. Glob. Aquac. Advocate 9, 62-63.

Boyd, C.E., 2005. Water use in aquaculture. World Aquac. 36, 12-15.

Boyd, C.E., Tucker, C., Mcnevin, A., Bostick, K., Clay, J., 2007. Indicators of resource use efficiency and environmental performance in fish and crustacean aquaculture. Rev. Fish. Sci. 15, 327-360, http://dx.doi.org/10.1080/10641260701624177.

Boyd, C.E., Tucker, C.S., 1998. Pond Aquaculture Water Quality Management. Springer US, Boston, MA

Bueno, G.W., Ostrensky, A., Canzi, C., de Matos, F.T., Roubach, R., 2015. Implementation of aquaculture parks in Federal Government waters in Brazil. Rev. Aquac. 7, 1-12, http://dx.doi.org/10.1111/raq.12045.

Bufon, A.G.M., Tauk-Tornisielo, S.M., Pião, A.C.S., 2009. Tempo de vida útil da Represa Velha da microbacia do Córrego da Barrinha, Pirassununga, SP, Brasil. Arq. Inst. Biológico 76, 673-679.

Campos, C.M., Ganeco, L.N., Castellani, D., Martins, M.I.E., 2007. Avaliação econômica da criação de tilápias em tanque-rede, município de Zacarias, SP. Bol. Inst. Pesca 33, 265-271.

Costanza, R., de Groot, R., Sutton, P., van der Ploeg, S., Anderson, S.J., Kubiszewski, I., Farber, S., Turner, R.K., 2014. Changes in the global value of ecosystem services. Glob. Environ. Change 26, 152-158, http://dx.doi.org/10.1016/j.gloenvcha.2014. 04.002.

Eaton, A.D., American Public Health Association, American Water Works Association, Water Environment Federation, 2005. Standard Methods for the Examination of Water and Wastewater. APHA-AWWA-WEF, Washington.

FAO, 2015. FishStat Plus - Universal Software for Fishery Statistical Time Series. FAO, Rome.

FAO, 2014. The State of World Fisheries and Aquaculture 2014: Opportunities and Challenges. FAO, Rome.

Frankic, A., Hershner, C., 2003. Sustainable aquaculture: developing the promise of aquaculture. Aquac. Int. 11, 517-530.

Garcia, F., Kimpara, J.M., Valenti, W.C., Ambrosio, L.A., 2014. Emergy assessment of tilapia cage farming in a hydroelectric reservoir. Ecol. Eng. 68, 72-79, http://dx. doi.org/10.1016/j.ecoleng.2014.03.076.

Giupponi, C., 2007. Decision support systems for implementing the European water framework directive: the MULINO approach. Environ. Model. Softw. 22, $248-258$.

Golterman, H.L., Climo, R.S., Ohnstad, M.A.M., 1978. Methods for Physical and Chemical Analysis of Fresh Waters, 2nd ed. IBP, Oxford.

Guo, L., Li, Z., 2003. Effects of nitrogen and phosphorus from fish cage-culture on the communities of a shallow lake in middle Yangtze River basin of China. Aquaculture 226, 201-212, http://dx.doi.org/10.1016/S0044-8486(03)00478-2.

Heink, U., Kowarik, I., 2010. What are indicators? On the definition of indicators in ecology and environmental planning. Ecol. Indic. 10, 584-593.

Holling, C.S., 1973. Resilience and stability of ecological systems. Annu. Rev. Ecol. Syst. 4, 1-23.

Huang, Y.A., Huang, S., Hsieh, H.J., Meng, P., Chen, C.A., 2012. Changes in sedimentation, sediment characteristics, and benthic macrofaunal assemblages around marine cage culture under seasonal monsoon scales in a shallow-water bay in Taiwan. J. Exp. Mar. Biol. Ecol. 422-423, 55-63.

ISO, 2006. ISO 14040: Environmental management - Life cycle assessment - Principles and framework. 
Johnston, P., Everard, M., Santillo, D., Robert, K.-H., 2007. Reclaiming the definition of sustainability. Environ. Sci. Pollut. Res. 14, 60-66.

Koroleff, F., 1976. Determination of nutrients. In: Grasshoff, K. (Ed.), Methods of Seawater Analysis. Verlag Chemie Weinhein, New York, pp. 117-181.

MPA, 2010. Produção pesqueira e aquícola: estatística 2008 e 2009. MPA, Brasília.

Nobre, A.M., 2009. An ecological and economic assessment methodology for coastal ecosystem management. Environ. Manage. 44, 185-204, http://dx.doi.org/10. 1007/s00267-009-9291-y.

Nobre, A.M., Robertson-Andersson, D., Neori, A., Sankar, K., 2010. Ecological-economic assessment of aquaculture options: comparison between abalone monoculture and integrated multi-trophic aquaculture of abalone and seaweeds. Aquaculture 306, 116-126, http://dx.doi.org/10.1016/j.aquaculture. 2010.06.002.

Odum, H.T., 1986. Emergy in ecosystems. In: Polunin, N. (Ed.), Environmental Monographs and Symposia. John Wiley, New York, pp. 337-369.

Rees, W.E., Wackernagel, M., 1994. Ecological footprints and appropriated carrying capacity: measuring the natural capital requirements of the human economy. In: Jansson, A., Hammer, M., Folke, C., Costanza, R. (Eds.), Investing in
Natural Capital: The Ecological Economics Approach to Sustainability. Island Press, Washington, pp. 362-389.

Sabbag, O.J., Rozales, R.R., Tarsitano, M.A.A., Silveira, A.N., 2007. Análise econômica da produção de tilápias (Oreochromisniloticus) em um modelo de propriedade associativista em Ilha Solteira/SP. São Paulo.

Shang, Y.C., 1990. Aquaculture Economic Analysis: An Introduction. World Aquaculture Society, Baton Rouge.

Valenti, W.C., 2012. Avanços e desafios tecnológicos para a sustentabilidade da carcinicultura. In: An. 49o Reunião Anu. Soc. Bras. Zootec. Produção Anim. No Mundo Em Transform. Brasília An.

Valenti, W.C., 2011. Measuring aquaculture sustainability. World Aquac. 42, 26-30.

Valenti, W.C., 2008. A aqüicultura Brasileira é sustentável. In: Palestra Apresentada Durante O IV Semin. Int. Aqüicultura Maric. E Pesca Aquafair 13-15.

Verdegem, M.C.J., Bosma, R.H., 2009. Water withdrawal for brackish and inland aquaculture, and options to produce more fish in ponds with present water use. Water Policy 11, 52-68.

WCED, 1987. Our Common Future. Oxford Paperbacks. 